\title{
Incidental findings in the oncology patient: liver
}

\author{
Wolfgang Schima \\ From International Cancer Imaging Society (ICIS) 14th Annual Teaching Course \\ Heidelberg, Germany. 9-11 October 2014
}

Technical advances in ultrasound, multi-detector computed tomography (MDCT) and magnetic resonance imaging (MRI) have increased our ability to detect small-sized hepatic lesions and low-contrast lesions, which would have escaped detection some years ago [1,2]. Prevalence of small lesions found at CT ranges from $12.7 \%$ to $29.4 \%$ in cancer patients [1-3]. Only a minority of these lesions will eventually turn out to be malignant. However, these incidental findings (or "incidentalomas", as they are called) detected in an oncologic patient pose a particular challenge for both the reporting radiologist and the referring clinician. Contrast-enhanced MRI has additional value in characterization of small lesions indeterminate at CT [4,5], but it has to be justified in terms of cost and resources in an individual patient. Management strategies are being developed to address these lesions, whether aggressive further evaluation (including contrast-enhanced MRI and/ or biopsy) or imaging follow-up is sought [6]. Seeking a "100\%-certainty strategy" may result in unnecessarily costly and invasive work-up of many patients. Decisions on further management should depend on the imaging appearance of incidentalomas, the history of the patients, risk assessment, taking into account further treatment options.

Imaging appearance of focal fatty infiltration and focal sparing of fat, which may mimic malignant disease, is presented. Small benign lesions, such as flash-filling hemangiomas, FNH, biliary hamartomas, or solitary necrotizing nodules can be difficult to diagnose in the setting of primary tumors with either hypervascular or hypovascular metastases, respectively. Strategies to approach these lesions and guide further management are presented.

Correspondence: wolfgang.schima@khgh.at

Department of Diagnostic and Interventional Radiology, Krankenhaus

Goettlicher Heiland, KH der Barmherzigen Schwestern, and Sankt Josef-

Krankenhaus, Vinzenzgruppe, Dornbacher Strasse 20-28, 1170 Vienna, Austria
Published: 9 October 2014

\section{References}

1. Schwartz LH, Gandras EJ, Colangelo SM, Ercolani MC, Panicek DM: Prevalence and importance of small hepatic lesions found at $C T$ in patients with cancer. Radiology 1999, 210:71-74.

2. Khalil HI, Patterson SA, Panicek DM: Hepatic lesions deemed too small to characterize at CT: prevalence and importance in women with breast cancer. Radiology 2005, 235:872-878.

3. Lim GH, Koh DC, Cheong WK, Wong KS, Tsang CB: Natural history of small, "indeterminate" hepatic lesions in patients with colorectal cancer. Dis Colon Rectum 2009, 52:1487-1491.

4. Holalkere NS, Sahani DV, Blake MA, Halpern EF, Hahn PF, Mueller PR: Characterization of small liver lesions: Added role of MR after MDCT. J Comput Assist Tomogr 2006, 30:591-596.

5. Baek SE, Park MS, Hong HS, et al: Characterisation of small hypoattenuating hepatic lesions in multi-detector CT (MDCT) in patients with underlying extrahepatic malignancy: added value of contrastenhanced MR images. Eur Radiol 2010, 20:2853-2861.

6. Berland LL, Silverman SG, Gore RM, et al: Managing incidental findings on abdominal CT: white paper of the ACR incidental findings committee. J Am Coll Radiol 2010, 7:754-773.

doi:10.1186/1470-7330-14-S1-042

Cite this article as: Schima: Incidental findings in the oncology patient: liver. Cancer Imaging 2014 14(Suppl 1):O42.

Submit your next manuscript to BioMed Central and take full advantage of:

- Convenient online submission

- Thorough peer review

- No space constraints or color figure charges

- Immediate publication on acceptance

- Inclusion in PubMed, CAS, Scopus and Google Scholar

- Research which is freely available for redistribution 